\title{
Efficiency of Simple Recurrent Selection and Selfing with Selection on Improving Growth, Yield and Quality of Pumpkin (Cucurbita Moschata)
}

\author{
Naglaa A.R. Omar, Abdel-Aziz M. Khalaf-Allah, Mahmoud A. \\ Wahb-Allah, Entesar I. M. Ragheb \\ Vegetable crops department, Faculty of Agriculture, Alexandria University \\ DOI: 10.21608/jalexu.2022.113162.1033
}

\section{Article Information}

Received:December $\quad 26^{\text {th }}$ 2021

Revised: January $5^{\text {th }} 2022$

Accepted: January $9^{\text {th }}$ 2022

Published: March $31^{\text {st }}$ 2022

ABSTRACT: It is important to give a good consideration towards the establishment of effective breeding programs for pumpkin purification and improvement. This study was carried out during three successive summer seasons of 2013 till 2015 to determine the effectiveness and efficiency of one cycle of simple recurrent selection and selfing with selection for two generations, as two breeding methods, to improve some important characters of pumpkin cultivar 'Balady'. Eight derived genetic populations; i. e, original population $\left(\mathrm{C}_{0}\right)$, one cycle of simple recurrent selection $\left(\mathrm{C}_{1}\right)$ and six selected progenies from selfing with selection for two generations $\left(S_{2}-1, S_{2}-2, S_{2}-3, S_{2}-\right.$ $4, S_{2}-5$ and $S_{2}-6$ ) were evaluated for vegetative, flowering, yield components and fruit quality characters. The results of the estimated values of coefficient of variation indicated that the original population $\left(\mathrm{C}_{0}\right)$ had an extensive range of variability which ranged from $13.55 \%$ for number of days to first female flower up to $71.83 \%$ for total yield/plant. The first cycle of recurrent selection enhanced the main stem length, number of branches/plant, average fruit weight and number of fruits/plant with about $122.60 \%, 157.50 \%, 338.30 \%$ and $243.33 \%$ respectively. Also, selfing with selection method for two generations enhanced main stem length within the range of $17.00 \%$ to $132.10 \%$, and number of branches per plant by $7.20 \%$ to $71.60 \%$, average fruit weight was noticed to be within the range of $65.10 \%$ to $285.46 \%$ and number of fruits/plant was within the range of $4.00 \%$ to $191.66 \%$ for all selected selfed progenies over that of the original population. The selected selfed progeny $\mathrm{S}_{2}$ 1 and $\mathrm{C}_{1}$ gave high improvement values of total yield/plant with about $189.91 \%$ and $148.69 \%$, respectively. The first cycle of recurrent selection was found to be apparently efficient in increasing and enhancing the general performances more than selfing with selection for two generations for most studied characters, except for number of days to first female flower and carotene content. Therefore, it may be concluded that recurrent selection seemed to be effective and efficient for developing of improved commercial pumpkin cultivar 'Balady'; whereas, selfing with selection can be successfully used to develop inbred lines for the production of hybrid or synthetic cultivar, out of the common commercial ones.

Keywords: Pumpkin, Cucurbita Moschata, individual selection, recurrent selection, breeding programs.

\section{INTRODUCTION}

Pumpkin (Cucurbita moschata Duch ex Poir, 2n= $40)$ is one of the important vegetable crops belonging to family Cucurbitaceae. It is considered as one of the essential and popular food crops in many tropical and sub-tropical countries. It is paramount as a good source of minerals, fibers, vitamins, carotenoids, antinutrients, antioxidants and phytonutrients. (Aruah et al. 2010). The consumption of pumpkins and pumpkin-based foods has been shown to confer several beneficial effects on human health due to their antioxidant capacity and terpenoid content. (Angel et. al. 2020 and Milorad et al. 2021). Pumpkin seed products can be added to wheat flour up to a $17 \%$ protein level for raw, roasted and autoclaved pumpkin meal, as well as the addition of pumpkin seed proteins resulted in increasing protein, lysine and mineral contents (El-Soukkary, 2001). The area allocated for the cultivation of pumpkin in Egypt is not estimated accurately. The production is mostly done on a small scale and the productivity of the growing cultivar is low. This lower productivity could be due to growing old local cultivar which is characterized by relatively low productive capacity.

It might be stated that no serious attempts have been so far made to purify and upgrade the productivity and suitability of pumpkin crop. Accordingly, it is important to give a good consideration towards the establishment of

Journal Article (C) 2021 by (JAAR) is licensed under CC BY-NC 4.0 CC) 
effective breeding programs for pumpkin purification and improvement. Genetic differences are the raw material of plant breeders where the success of breeding program is depending on the amount of variability present in the original population for the studied crop. Therefore, information on the variability existed in a group of pumpkin populations are essential. High variability as values of coefficient of variation was observed for most characters of pumpkin genotypes (Alsadon et al. 1998, Pandey et al. 2002, Pandey et al. 2008, and Solieman 2009).

Recurrent selection is one of the efficient selection methods that are usually used for improving open-pollinated crops and leading to the identification of superior genotypes. It is considered as an effective breeding method of achieving improvement of quantitative characters within a population through maintaining genetic variability. Consequently, natural vigor in cross pollinated crops allows for the concentration of desirable alleles and increases the frequency of superior recombination in successive populations. Breeders often practice inbreeding to confirm desirable characteristics within a population. In plant breeding, inbred lines are used as stocks for the creation of hybrid populations to make use of the heterosis effect. Inbreeding in plants occurs naturally in the form of self-pollination. In many cases, inbreeding with selection increases the effectiveness of selection and the amount of genetic improvement in a breeding program by increasing the frequency of the desirable alleles. The significant inbreeding depression for all the yield characters in pumpkin (Cucurbita moschata Duch. ex. Poir.), except number of fruits per vine, was observed (Jansi et al. 2018).

Yield and traits related to fruit quality were evaluated for six pumpkin introductions (Cucurbita moschata Duch.) from openpollination and their respective inbreeding line $\left(S_{1}\right.$ and $S_{2}$ ) by Grisales et al. 2009. They reported that the inbreeding that was accompanied with selection did not cause negative effects on yield, nor the agribusiness characters; fruit pulp weight and color, and fruit dry matter. The local Egyptian pumpkin cultivar was improved through the two practiced breeding methods; one cycle of simple recurrent selection and selfing with selection for two generations, but with different magnitudes among the characters and the used breeding methods (Solieman 2009). Several investigators used recurrent selection or/and selfing with selection methods to improve the various economical characters of pumpkin crop such as. Alsadon et al. 1998, Hazara et al. 2007, Pandey et al. 2008 and Srikanth et al. 2017.

This study is a part of comprehensive breeding program aimed to improve productivity and quality of Egyptian local cultivar 'Balady' of pumpkin (Cucurbita moschata). The purposes of the present investigation are comparing the efficiency of two breeding methods; one cycle of simple recurrent selection and selfing with selection for two generations in improving some important characters of "Balady" pumpkin cultivar. Percentage of heritability in broad sense and variance components for each of the growth and productivity traits were considered in this investigation. The main goal of this research aimed to improve some important characteristics of the pumpkin cultivar "Balady".

\section{MATERIALS AND METHODS}

This study was carried out during three successive summer seasons of 2013 till 2015, at the Experimental Station Farm, Faculty of Agriculture, Alexandria University, at Abies, Alexandria, Egypt. Simple recurrent selection for one cycle and selfing with selection for two generations, as two breeding methods, were used to improve some important characters of pumpkin (Cucurbita moschata Duch ex Poir, $2 n=40$ ). The original genetic material consisted of the commercial cultivar of pumpkin crop 'Balady'. This cultivar was chosen since it commonly grown and well adapted to local environmental conditions of Egypt.

\section{Evaluation of the Original Population and First Season for the Breeding Methods:}

Seeds of the original population of pumpkin cultivar 'Balady' were sown on April $20^{\text {th }}$ of April, 2013.The experimental area consisted of 115 rows, $4.0 \mathrm{~m}$ long and $2.5 \mathrm{~m}$ wide. The spacing between plants within rows was $80 \mathrm{~cm}$. The total number of plants for this population was 570. To determine the magnitude and importance of genetic variability for the original population of pumpkin, the statistical parameters, i.e., mean, range and coefficient of variation (C.V. \%) were estimated. These parameters were estimated for twelve characters (main stem length, number of branches/plant, number of days to first female flower, sex ratio, flesh thickness, number of fruits/plant, average fruit weight, total yield/plant, dry matter percentage, total soluble solids, carotene content and total sugars) during different growth stages.

Initial visual selection was made in the growing original population of pumpkin 'Balady' Only 227 plants from the 570 plants were selected to begin the procedures of the two selection methods; simple recurrent selection and selfing with selection for two generations. The selection procedures were made according to the measurements of the different studied characters, individual plant basis, depending on the degree of the taller main stem length, a greater number of 
branches/plant, fewer number of days to first female flower, close sex ration, thicker flesh thickness, more number of fruits/plant and high content of chemical constituents (dry matter, total soluble solids, total carotenoids and total sugars contents). Selfed seeds of the best 12 plants were selected from the original population (227 growing plants) according to the previously mentioned characters.

At the end of fruit maturity stage, selfed seeds from each selected families, twelve families, of pumpkin were separately harvested as well as seeds of the original population were separately collected and extracted. Selfed seeds of all selected plants were obtained by the end of September, 2013. The seeds of the twelve selected families were divided to equal parts for two groups: the first group represents the seeds of the first selfed progenies; while, the second group was bulked to start the second season of simple recurrent selection.

\section{Second Season of Recurrent Selection and Selfing with Selection:}

In the second season on April 23 $3^{\text {th }}$ of April, 2014, seeds of each of the two selection methods, first season of recurrent selection and the first selfed progenies of each selected plant (twelve families), were separately sown; then, selection on the same forgoing basis were made. For simple recurrent selection, bulked seeds of the first season of simple recurrent selection were sown at 40 rows to represent base of the second season of the first cycle of simple recurrent selection. At flowering stage the plants were left for open-pollination to produce the seeds of the first cycle of simple recurrent selection $\left(\mathrm{C}_{1}\right)$. For selfing with selection method, seeds of each selected plant, twelve families, were cultivated in the form of separated families (50 plants for each family). Then the practices of selection between and within the selfed progenies of each $S_{1}$ families on the same foregoing basis were conducted. At flowering stage, some flowers were selfed, to produce the seeds of the second selfed progenies $\left(S_{2}\right)$. At the end of the growing season selfed seeds of six families, according to selection between families, were separately collected to get the final selected selfed progenies $\left(\mathrm{S}_{2}\right)$ which came out to be six progenies.

Evaluation of Genetic Populations:

In this experiment seeds of each of the eight derived genetic populations; i. e, original population $\left(\mathrm{C}_{0}\right)$, one cycle of simple recurrent selection $\left(\mathrm{C}_{1}\right)$ and the six selected progenies derived from selfing with selection for two generations $\left(S_{2}-1, S_{2}-2, S_{2}-3, S_{2}-4, S_{2}-5\right.$ and $\left.S_{2}-6\right)$ were separately sown on April 26, 2015, in a randomized complete blocks design (R.C.B.D), with three replicates. Each plot was represented by two rows, $4 \mathrm{~m}$ long and $2.50 \mathrm{~m}$ wide and 0.80 $\mathrm{m}$ between growing plants. The common cultural practices were carried out according to the recommended practices for commercial pumpkin production.

\section{Data Recorded:}

The vegetative and flowering characters were recorded on random samples of five plants from each plot. At the end of the growing season, the main stem length (m) was measured from the first node up to the terminal bud, and the total number of main branches of each sample from each plot was counted. Number of days to the first female flower was recorded as the number of elapsed days from sowing to opining of the first female flower. Sex ratio (\%) was determined by dividing the number of staminate flowers by the number of pistillate flowers.

Sample of five random fruits at the mature stage of each experimental plot, were taken to determine flesh thickness (in $\mathrm{cm}$ using a rural) and average fruit weight $(\mathrm{Kg})$ (determined by dividing total fruits weight by their total number). The number of fruits/plant and total yield/plant $\mathrm{Kg}$ ) were recorded for all growing plants in each plot.

A random sample of 8 fruits from each experimental plot was taken to determine fruit dry matter (\%), total soluble solids (\%), total carotenoid content (according to the method described by Davies 1976, and expressed as mg. $100 \mathrm{~g}^{-1}$ f.w) and total sugars (\%) (according to Nelson's method as illustrated by Malik and Singh 1980.

\section{Statistical Analysis}

The statistical analysis of the recorded data of all various pumpkin characters were carried out using the standard method of the analysis of variance of the randomized complete blocks design, as illustrated by Al-Rawi and KhalafAllah (1980); using Co-stat software (2004), a computer program for statistics of the differences between means. Heritability in broad sense was estimated through variance components methods according to Allard (1960). 
RESULTS

Variability Estimates for the Original Population of Pumpkin:

The magnitude and importance of genetic variability for the original population of pumpkin was determined by estimating the statistical more than double of the population mean. The results of the estimated values of coefficient of variation, obviously, indicated that the original population $\left(\mathrm{C}_{0}\right)$ had an extensive range of variability which ranged from $13.55 \%$ for number of days to first female flower up to $71.83 \%$ for total yield/plant. The coefficient of variation values were more than $50 \%$ for five characters; sex ratio, number of fruits/plant, total yield/plant, parameters mean, range and coefficient of variation for all studied characters (Table 1). The results of the estimated values of mean and range for the different characters showed that the range value for each character was wide and reached

carotene content, and total sugars content. Moreover, it ranged between $25 \%$ and $50 \%$ for five characters; main stem length, number of branches/plant, average fruit weight, dry matter content and total soluble solid. However, it was less than $25 \%$ only for number of days to first female flower and flesh thickness.

Table 1. Mean, range and coefficient of variation (CV\%) for the studied characters in the original population of pumpkin cultivar 'Balady'.

\begin{tabular}{llll}
\hline Characters & Mean & Range & C.V. \% \\
\hline Main stem length (m) & 4.80 & $1.00-12.00$ & 41.69 \\
No. branches/plant & 3.57 & $1.00-7.00$ & 32.98 \\
No. days to first female flower & 50.82 & $37.00-80.00$ & 13.55 \\
Sex ratio (\%) & 13.28 & $1.42-46.10$ & 55.80 \\
Flesh thickness (cm) & 3.58 & $1.30-6.50$ & 24.62 \\
Average fruit weight (kg) & 4.42 & $0.60-12.50$ & 48.38 \\
No. fruits/plant & 2.05 & $1.00-6.00$ & 53.95 \\
Total yield/plant (kg) & 9.02 & $0.60-39.40$ & 71.83 \\
Dry matter (\%) & 7.02 & $0.56-13.04$ & 35.13 \\
Total soluble solids (T.S.S)\% & 6.48 & $2.00-13.30$ & 30.22 \\
Carotene content (mg/100gm.fw) & 2.07 & $0.29-7.32$ & 55.03 \\
Total sugars (\%) & 6.32 & $1.15-24.96$ & 69.96 \\
\hline
\end{tabular}

General Performances and Variability Magnitude of the Studied Genetic Populations: Vegetative growth and flowering characters

The results concerning vegetative growth and flowering characters means, range and coefficient of variation of the eight different genetic populations; original population of pumpkin cultivar 'Balady' $\left(\mathrm{C}_{0}\right)$, population derived from the first cycle of simple recurrent selection $\left(\mathrm{C}_{1}\right)$ and the second selfed progenies of the six individual selections $\left(S_{2}-1, S_{2}-2, S_{2}-3, S_{2}-4, S_{2}-5\right.$ and $\left.S_{2}-6\right)$; are presented in Table (2). Generally, the second selfed progeny $\mathrm{S}_{2}-3$ was noticed to significantly have the highest mean value for main stem length 
(JAAR) Volume: 27 (1)

Table 2. Mean, range and coefficient of variation (C.V. \%) for vegetative and flowering characters in the eight populations of pumpkin.

\begin{tabular}{|c|c|c|c|c|c|c|}
\hline \multirow{2}{*}{$\begin{array}{l}\text { Genetic } \\
\text { populations }\end{array}$} & \multicolumn{3}{|c|}{ Main stem length (m) } & \multicolumn{3}{|c|}{ No. of branches/plant } \\
\hline & Mean & Range & C.V. \% & Mean & Range & C.V. \% \\
\hline $\mathrm{C}_{0}$ & $4.10 \mathrm{e}$ & $2.80-11.80$ & 37.64 & $2.33 \mathrm{~d}$ & $1.00-6.00$ & 40.46 \\
\hline $\mathbf{C}_{1}$ & $9.13 \mathrm{ab}$ & $4.00-11.50$ & 27.97 & $6.00 \mathrm{a}$ & $3.00-7.00$ & 26.55 \\
\hline $\mathbf{S}_{2-1}$ & $6.53 \mathrm{~cd}$ & $6.00-9.70$ & 14.88 & $4.00 \mathrm{~b}$ & $3.00-5.00$ & 18.17 \\
\hline $\mathbf{S}_{2-2}$ & $4.80 \mathrm{e}$ & $3.10-10.20$ & 25.67 & $2.20 \mathrm{~d}$ & $2.00-5.00$ & 24.88 \\
\hline $\mathbf{S}_{2-3}$ & $9.52 \mathrm{a}$ & $4.15-11.50$ & 21.90 & $3.75 \mathrm{bc}$ & $2.00-4.00$ & 21.08 \\
\hline$S_{2-4}$ & $5.83 \mathrm{~d}$ & $3.25-11.10$ & 24.67 & $2.85 \mathrm{~cd}$ & $2.00-4.00$ & 19.83 \\
\hline$S_{2}-5$ & $8.45 \mathrm{~b}$ & $3.30-9.70$ & 22.41 & $2.50 \mathrm{~d}$ & $1.00-4.00$ & 22.39 \\
\hline \multirow[t]{3}{*}{$S_{2}-6$} & $6.73 \mathrm{c}$ & $4.20-11.50$ & 26.18 & $3.73 \mathrm{bc}$ & $3.00-5.00$ & 18.32 \\
\hline & \multicolumn{3}{|c|}{ No. of days to first female flower } & \multicolumn{3}{|c|}{ Sex ratio $(\%)$} \\
\hline & Mean & Range & C.V. \% & Mean & Range & C.V. \% \\
\hline $\mathbf{C}_{0}$ & $53.33 \mathrm{a}$ & $45.00-57.00$ & 6.11 & $12.00 \mathrm{a}$ & $5.00-15.00$ & 32.11 \\
\hline $\mathbf{C}_{1}$ & $45.23 \mathrm{e}$ & $45.00-52.00$ & 5.55 & $5.63 \mathrm{e}$ & $3.30-12.30$ & 30.78 \\
\hline $\mathbf{S}_{2}-1$ & $50.00 \mathrm{bc}$ & $45.00-55.00$ & 4.18 & $5.40 \mathrm{e}$ & $4.90-13.80$ & 28.98 \\
\hline$S_{2}-2$ & $47.83 \mathrm{~cd}$ & $45.00-50.00$ & 5.52 & $7.50 \mathrm{~cd}$ & $4.00-10.10$ & 20.56 \\
\hline $\mathbf{S}_{2}-3$ & $48.70 \mathrm{~cd}$ & $45.00-55.00$ & 5.54 & $12.60 \mathrm{a}$ & $7.70-14.30$ & 18.10 \\
\hline$S_{2}-4$ & $47.73 \mathrm{~d}$ & $47.00-55.00$ & 5.00 & $7.90 \mathrm{c}$ & $6.10-18.80$ & 31.97 \\
\hline$S_{2}-5$ & $51.00 \mathrm{~b}$ & $47.00-50.00$ & 5.90 & $6.50 \mathrm{de}$ & $5.90-12.50$ & 20.60 \\
\hline$S_{2-6}$ & $44.00 \mathrm{e}$ & $42.00-55.00$ & 6.25 & $9.20 \mathrm{~b}$ & $7.60-12.10$ & 13.94 \\
\hline
\end{tabular}

Values having a similar alphabetical letter, within a comparable group of means, are not significantly differ; using Revised LSD test at 0.05 probability level.

character, followed by that of the $\mathrm{C}_{1}$ population. However, $\mathrm{C}_{1}$ population significantly had the highest mean value for number of branches/plant, followed by that of $S_{2}-1, \quad S_{2}-3$ and $S_{2}-6$ populations without significant differences among the later three progenies. On the other hand, $\mathrm{C}_{0}$ had the lowest mean value for both stem length and number of branches/plant characters. The comparisons among mean values of number of days to the first female flower and sex ratio of the different eight evaluated populations clarified that the $C_{1}$ population reflected desirable significant lowest value, followed by that of $S_{2}-6$ and $S_{2}-1$ for number of days and sex ratio, respectively. It was also noticed that all the other second selfed progenies significantly gave lower mean values than that of the $\mathrm{C}_{0}$ population. Therefore, it is a positive result to improve earliness characters.

The data of variability magnitude, expressed as range and coefficient of variation, illustrated that a reduction in variability was detected in all selected populations relative to the original population $\left(\mathrm{C}_{0}\right)$, but with different degrees (Table $2)$. Generally, all populations relatively reflected extensive ranges. The widest range was reflected by $\mathrm{C}_{0}$ population, while, close range was reflected by second selfed progenies $\left(\mathrm{S}_{2}\right)$. The estimated values of range and C.V.\% for main stem length and number of branches/plant characters showed that the variability estimate was reduced in all selected populations, compared with the original population. However, it was noticed that $\mathrm{C}_{1}$ population (recurrent selection method) tended to relatively maintain higher variability than all $S_{2}$ populations (selfing with selection method), as appeared from the comparisons among the C.V. values of the various genetic populations. All of the six selected progenies derived from selfing with selection for two generations appeared to have lower estimates for the coefficient of variations than that shown by the $\mathrm{C}_{1}$. The coefficient of variation for number of days to first female flower was found to be $6.11 \%$ in the original population $\left(\mathrm{C}_{0}\right)$. After the first cycle of recurrent selection, the variability magnitude was reduced to $5.55 \%$. The second selfed progeny populations recorded very close C.V. values; except $\mathrm{S}_{2}-6$ which gave the highest estimated CV\% value (6.25\%) among all tested genetic populations (Table 2). The variability of sex ratio was reduced after the two selection methods. The variability magnitude was slightly decreased to be $30.78 \%$ at $\mathrm{C}_{1}$ and to $31.97 \%$ at $\mathrm{S}_{2}-4$. However, the other second selfed progenies clearly showed decrease variability than the original population. Moreover, $\mathrm{S}_{2}-6$ gave the lowest estimated value of C.V. \% which was $13.94 \%$.

The enhancement percentage for vegetative and flowering characters in the selected genetic populations as compared to the original population are presented in (Fig. 1.) Populations $S_{2}-3, C_{1}$ and $S_{2}-5$ were found to be highly efficient in increasing stem length character with about $132.10 \%, \quad 122.60 \%$ and $106.00 \%$, respectively, over the original population (Fig.1a). However, $C_{1}$ was apparently efficient in increasing number of branches/plant with about $157.50 \%$. Also, $S_{2}-1, S_{2}-3$ and $S_{2}-6$ enhanced this character by $71.60 \%, 60.90 \%$ and 
A

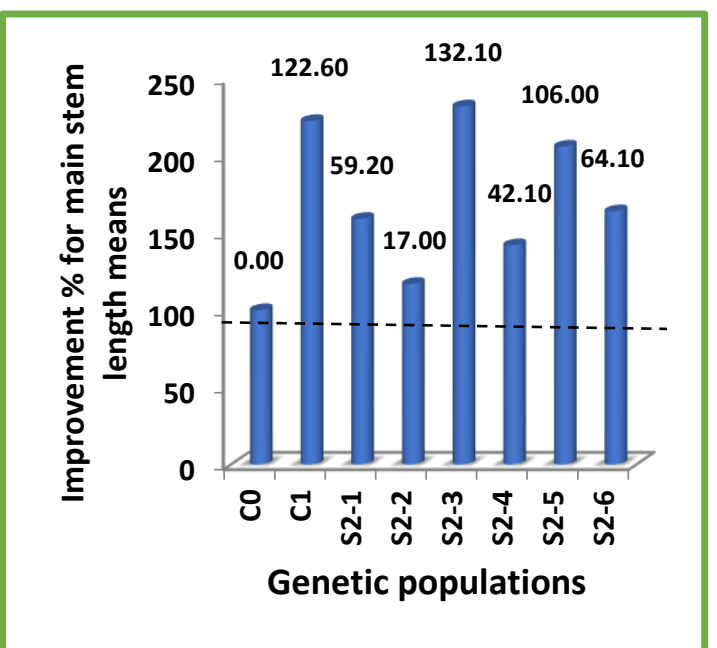

C

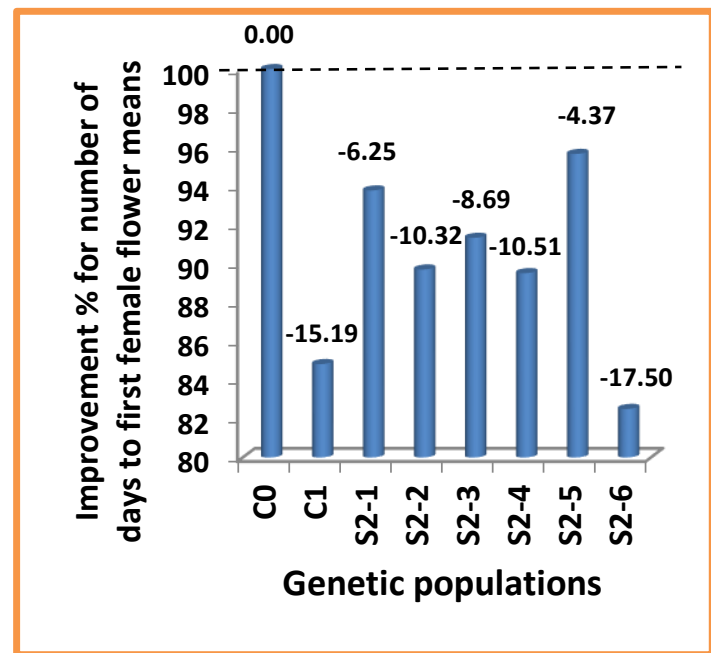

B
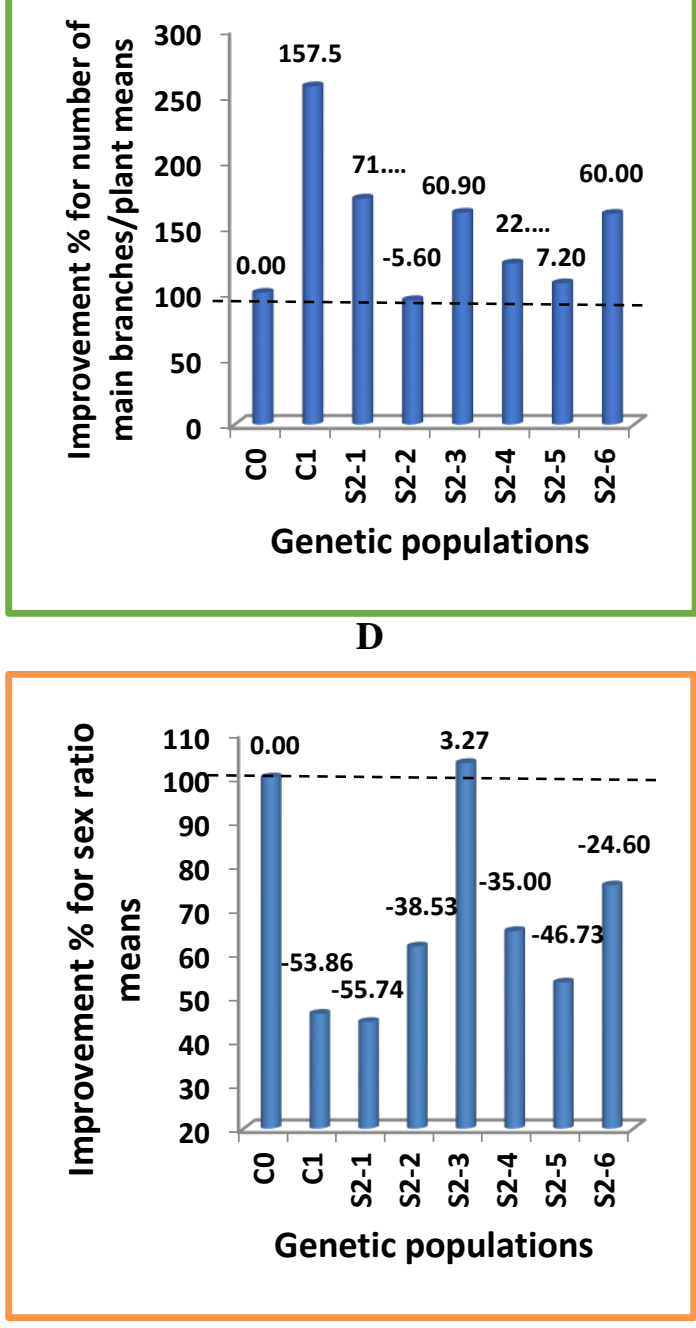

Fig. 1. The enhancement percentage for vegetative and flowering characters in the selected genetics populations as compared to the original population.

$\mathrm{C}_{0}=$ The original population of pumpkin cultivar " Balady".

$\mathrm{C}_{1}=$ The population derived from the first cycle of simple recurrent selection.

$S_{2}-1: S_{2}-6=$ The six selected progenies derived from selfing with selection for two generations. 
$60.00 \%$, respectively. While, increasing rate was relatively low in the cases of $\mathrm{S}_{2}-4$ and $\mathrm{S}_{2}-5$ with about $22.30 \%$ and $7.20 \%$. On the contrary, there is no improvement recorded in $\mathrm{S}_{2}-2$, which reduced number of branches by $5.60 \%$ from the original population (Fig.1b). The data in (Fig.1c) showed that $C_{1}$ and $S_{2}-6$ reflected lower number of days to first female flower by $15.19 \%$ and $17.50 \%$, respectively. It was, also, noticed that all the other selected selfed progenies enhanced this character compared with $\mathrm{C}_{0}$ population by $10.51 \%$ in $\mathrm{S}_{2}-4,10.32 \%$ in $\mathrm{S}_{2}-2,8.69 \%$ in $\mathrm{S}_{2}-3$, $6.25 \%$ in $\mathrm{S}_{2}-1$ and $4.37 \%$ in $\mathrm{S}_{2}-5$. The enhancement percentage of sex ratio trait; expressed in low value; are shown in Fig. (1d).
$\mathrm{S}_{2}-1$ and $\mathrm{C}_{1}$ gave high efficiency to improve this trait, which gave the highest percentage of improvement values with about $55.74 \%$ and $53.86 \%$, respectively. The other selected selfed progenies, also, reflected some improvement for this character with different degrees.

\section{Fruits, yield and its components characters}

The results concerning fruits, yield and its components characters of the different studied populations of the pumpkin cultivar 'Balady' are listed in Table (3). The comparisons between the two selection methods; simple recurrent selection and selfing with

Table 3. Mean, range and coefficient of variation (C.V. \%) for fruits and yield characters in the eight populations of pumpkin.

\begin{tabular}{|c|c|c|c|c|c|c|}
\hline \multirow{2}{*}{$\begin{array}{l}\text { Genetic } \\
\text { populations }\end{array}$} & \multicolumn{2}{|c|}{ Flesh thickness (cm) } & \multicolumn{4}{|c|}{ Average fruit weight (kg) } \\
\hline & Mean & Range & C.V. \% & Mean & Range & C.V. \% \\
\hline $\mathrm{C}_{0}$ & $2.13 \mathrm{f}$ & $2.00-6.00$ & 30.78 & $1.72 \mathrm{~h}$ & $1.50-9.60$ & 45.71 \\
\hline $\mathbf{C}_{1}$ & $6.43 \mathrm{a}$ & $3.00-7.00$ & 27.22 & $7.54 \mathrm{a}$ & $1.10-8.30$ & 37.54 \\
\hline$S_{2-1}$ & $5.10 \mathrm{~b}$ & $2.50-5.50$ & 25.43 & $4.66 \mathrm{~d}$ & $1.20-6.65$ & 31.82 \\
\hline $\mathbf{S}_{2-2}$ & $2.83 \mathrm{e}$ & $2.00-4.50$ & 20.08 & $3.36 \mathrm{f}$ & $2.15-6.40$ & 33.68 \\
\hline $\mathbf{S}_{2-3}$ & $3.63 \mathrm{~d}$ & $2.00-5.50$ & 23.61 & $2.84 \mathrm{~g}$ & $2.25-7.00$ & 31.13 \\
\hline$S_{2}-4$ & $4.30 \mathrm{c}$ & $2.50-6.00$ & 21.37 & $5.75 \mathrm{c}$ & $1.10-7.10$ & 31.25 \\
\hline $\mathbf{S}_{2-5}$ & $3.05 \mathrm{e}$ & $2.00-5.00$ & 22.60 & $6.63 \mathrm{~b}$ & $1.45-7.50$ & 33.01 \\
\hline \multirow[t]{3}{*}{$S_{2}-6$} & $3.86 \mathrm{~d}$ & $2.50-5.00$ & 18.76 & $3.83 \mathrm{e}$ & $2.76-5.65$ & 18.86 \\
\hline & \multicolumn{2}{|c|}{ No. of fruits/plant } & & \multicolumn{3}{|c|}{ Total yield/plant (kg) } \\
\hline & Mean & Range & C.V. \% & Mean & Range & C.V. \% \\
\hline $\mathrm{Co}_{0}$ & $1.00 \mathrm{f}$ & $1.00-5.00$ & 66.68 & $5.75 \mathrm{~g}$ & $1.50-19.80$ & 59.00 \\
\hline $\mathbf{C}_{1}$ & $4.12 \mathrm{a}$ & $1.00-6.00$ & 48.67 & $14.30 \mathrm{~b}$ & $1.10-22.30$ & 40.89 \\
\hline$S_{2-1}$ & $3.50 \mathrm{~b}$ & $1.00-5.00$ & 29.04 & $16.67 \mathrm{a}$ & $1.20-24.40$ & 42.39 \\
\hline $\mathbf{S}_{2-2}$ & $2.00 \mathrm{~d}$ & $1.00-5.00$ & 40.45 & $12.53 \mathrm{c}$ & $2.40-15.70$ & 39.20 \\
\hline $\mathbf{S}_{2-3}$ & $1.62 \mathrm{de}$ & $1.00-4.00$ & 35.60 & $8.06 \mathrm{e}$ & $2.70-16.00$ & 40.04 \\
\hline$S_{2-4}$ & $2.58 \mathrm{c}$ & $1.00-5.00$ & 50.00 & $12.66 \mathrm{c}$ & $3.80-21.70$ & 41.07 \\
\hline$S_{2-5}$ & $1.25 \mathrm{ef}$ & $1.00-3.00$ & 35.09 & $7.06 \mathrm{f}$ & $2.90-21.00$ & 48.31 \\
\hline$S_{2-6}$ & $3.11 \mathrm{bc}$ & $1.00-5.00$ & 48.34 & $11.22 \mathrm{~d}$ & $3.30-17.80$ & 42.86 \\
\hline
\end{tabular}

Values having a similar alphabetical letter, within a comparable group of means, are not significantly differ; using Revised LSD test at 0.05 probability level.

selection, reflected noticeable efficiency for increasing these characters in all selected populations, since the means of the derived populations appeared to be significantly higher than that of the original population. The highest mean value of each character of all evaluated populations was recorded by $\mathrm{C}_{1}$, followed by those of the two selfed progenies $S_{2}-1$ and $S_{2}-5$. While, the lowest mean values were given by the original population $\left(\mathrm{C}_{0}\right)$. Flesh thickness, average fruit weight, number of fruits/plant and total yield/plant means significantly increased after the first cycle of recurrent selection $\left(\mathrm{C}_{1}\right)$ from 2.13 $\mathrm{cm}, 1.72 \mathrm{~kg}, 1.00$ fruits/plant and $5.75 \mathrm{~kg} /$ plant in $\mathrm{C}_{0}$ population to $6.43 \mathrm{~cm}, 7.54 \mathrm{~kg}, 4.12$ fruits /plant and $14.3 \mathrm{~kg} /$ plant in $\mathrm{C}_{1}$, respectively. These results indicated that the first cycle of simple recurrent selection and the second selfed progenies $S_{2}-1$ and $S_{2}-5$ were highly efficient in increasing fruits, yield and its components characters.

Range and C.V. \% values presented in Table (3) reflected that the eight studied populations had extensive range values for flesh thickness and average fruit weight characters and the original population reflected wide range of variability. Selfing with selection was effective in decreasing the variability of both traits. On the other hand, the first cycle of recurrent selection reflected the lowest reduction in variability compared to the original population. The data for number of fruits/plant relatively reflected lower variability in the second selfed progenies $\mathrm{S}_{2}-1, \mathrm{~S}_{2}-3$ and $\mathrm{S}_{2}-5$ populations $(29.04 \%, 35.60 \%$ and $35.09 \%$, respectively) than that of the original population $(66.68 \%)$. Whereas, the $C_{1}$ and the other three selfed progenies $\left(S_{2}-2, S_{2}-4\right.$ and $\left.S_{2}-6\right)$ relatively maintained higher variability than that of the later populations; but it is still lower than the 
variability in the original population. However, for total yield character, the estimated values for the C.V.\% and range values reflected wide range and pronounced variability magnitudes in all populations. The results clarified, also, that despite the apparent decrease in variability magnitude for the selected populations, it still had wide variability magnitude. The estimated coefficients of variation values were found to be $59.00 \%$ in $\mathrm{C}_{0}, 40.89 \%$ in $\mathrm{C}_{1}$ and from $39.20 \%$ to $48.31 \%$ for the six selfed progenies.

The percentage of improvement for flesh thickness increased in all derived genetic populations (Fig. 2 a). Where, $\mathrm{C}_{1}$ reflected increment with about $201.87 \%$, followed by $\mathrm{S}_{2}-1$, $\mathrm{S}_{2}-4$ and $\mathrm{S}_{2}-6$, which increased over that of $\mathrm{C}_{0}$ by $139.43 \%, 101.87 \%$ and $81.22 \%$, respectively. The percentage of increase in average fruit weight values presented in Fig. ( 2 b) extremely reflected increment of enhancement in $\mathrm{C}_{1}$ population over that of $\mathrm{C}_{0}$ with about $338.37 \%$, followed by those of the $S_{2}-5, S_{2}-4, S_{2}-1$ and $S_{2}-6$ with about $285.46 \%, 234.30 \%, 170.93 \%$ and $122.60 \%$, respectively. $C_{1}$ and $S_{2}-1, S_{2}-6$ were found to be efficient in increasing number of fruits/plant character with about $243.33 \%, 191.66 \%$, and $159.16 \%$, respectively, while the improvement rate was relatively low in the two selfed progenies $\mathrm{S}_{2}-3$ and $\mathrm{S}_{2}-5$ with about $35.00 \%$ and $4.00 \%$ (Fig. $2 \mathrm{c})$. Data on the percentage of improvement of total yield/plant illustrated that $S_{2}-1$ and $C_{1}$ gave high improvement percentage with about $189.91 \%$ and $148.69 \%$, respectively. The improvement rate was relatively low in $\mathrm{S}_{2}-3$ and $\mathrm{S}_{2}-5$ with about $40.17 \%, 22.78 \%$ over that of the original population.

\section{Chemical constituents of fruits characters}

The results concerning chemical constituents of fruits characters of the eight different genetic populations are presented in Table (4). Those comparisons illustrated that the first recurrent selection cycle produced the highest mean value of dry matter percentage that significantly differed from that of the original population as well as the six selfed progenies, followed by those of the second selfed progeny $S_{2}-3$ and $S_{2}-1$ with significant differences. After the first cycle of recurrent selection, the total soluble solids value significantly increased relative to the original population. In the case of selfing with selection, the comparisons among the mean values clarified that all of the selected selfed progenies showed efficiency in increasing total soluble solids higher than $\mathrm{C}_{0}$, where $\mathrm{S}_{2}-1$ gave the highest significant mean value (9.26). Carotene content means for the selected populations compared to the original population reflected different responses. Where, it significantly increased in some populations and significantly decreased in the others. The second selfed progeny $S_{2}-5$ was noticed to significantly have the highest mean value (9.20) for carotene content, followed by $S_{2}-6$ (7.39) and $C_{1}$ (6.93). The mean value given by the original population was 5.33. Concerning total sugar character, the results illustrated that

Table 4. Mean, range and coefficient of variation (C.V. \%) for chemical constituents of fruits characters in the eight populations of pumpkin.

\begin{tabular}{|c|c|c|c|c|c|c|}
\hline \multirow{2}{*}{$\begin{array}{l}\text { Genetic } \\
\text { populations }\end{array}$} & \multicolumn{3}{|c|}{ Dry matter (\%) } & \multicolumn{3}{|c|}{ Total soluble solids (\%) } \\
\hline & Mean & Range & C.V. \% & Mean & Range & C.V. \% \\
\hline $\mathrm{C}_{0}$ & $3.61 \mathrm{~g}$ & $2.29-9.70$ & 36.47 & $4.07 \mathrm{~g}$ & $3.00-10.30$ & 26.86 \\
\hline $\mathbf{C}_{1}$ & $10.81 \mathrm{a}$ & $6.00-13.75$ & 22.68 & $7.36 \mathrm{~d}$ & $5.00-11.00$ & 20.42 \\
\hline$S_{2-1}$ & $7.74 \mathrm{c}$ & $6.00-15.20$ & 22.18 & $9.26 \mathrm{a}$ & $6.40-10.00$ & 13.40 \\
\hline $\mathbf{S}_{2-2}$ & $6.39 \mathrm{de}$ & $3.10-8.91$ & 18.53 & $6.48 \mathrm{e}$ & $3.20-8.00$ & 18.29 \\
\hline $\mathbf{S}_{2-3}$ & $9.30 \mathrm{~b}$ & $4.30-12.00$ & 24.29 & $7.92 \mathrm{c}$ & $6.00-8.50$ & 11.14 \\
\hline$S_{2-4}$ & $5.08 \mathrm{f}$ & $3.40-9.90$ & 24.29 & $8.81 \mathrm{~b}$ & $4.20-10.50$ & 19.25 \\
\hline$S_{2-5}$ & 5.35 ef & $4.43-10.00$ & 21.85 & $5.32 \mathrm{f}$ & $3.80-8.90$ & 18.49 \\
\hline \multirow[t]{3}{*}{$S_{2}-6$} & $7.07 \mathrm{~cd}$ & $5.00-11.50$ & 23.39 & $5.43 \mathrm{f}$ & $4.50-7.30$ & 15.09 \\
\hline & \multicolumn{3}{|c|}{ Carotene content (mg/100gm.fw) } & \multicolumn{3}{|c|}{ Total sugars (\%) } \\
\hline & Mean & Range & C.V. \% & Mean & Range & C.V.\% \\
\hline $\mathbf{C}_{0}$ & $5.33 \mathrm{e}$ & $3.60-13.00$ & 37.18 & $3.90 \mathrm{f}$ & $2.86-24.6$ & 64.85 \\
\hline $\mathbf{C}_{1}$ & $6.93 \mathrm{c}$ & $4.36-8.89$ & 20.08 & $7.31 \mathrm{a}$ & $4.90-8.12$ & 12.91 \\
\hline$S_{2-1}$ & $5.64 \mathrm{e}$ & $4.90-12.00$ & 25.25 & $6.03 \mathrm{~cd}$ & $4.53-8.10$ & 15.44 \\
\hline $\mathbf{S}_{2-2}$ & $4.73 \mathrm{f}$ & $4.01-7.45$ & 16.54 & $6.42 \mathrm{bc}$ & $3.90-7.06$ & 12.43 \\
\hline $\mathbf{S}_{2-3}$ & $3.72 \mathrm{~g}$ & $3.00-7.65$ & 22.02 & $5.56 \mathrm{~d}$ & $5.09-7.81$ & 13.36 \\
\hline$S_{2-4}$ & $6.20 \mathrm{~d}$ & $5.00-7.60$ & 11.94 & $6.64 \mathrm{abc}$ & $4.95-7.49$ & 12.41 \\
\hline$S_{2-5}$ & $9.20 \mathrm{a}$ & $4.50-10.50$ & 28.66 & $4.68 \mathrm{e}$ & $4.40-7.80$ & 16.84 \\
\hline
\end{tabular}

Values having a similar alphabetical letter, within a comparable group of means, are not significantly differ; using Revised LSD test at 0.05 probability level. 
a

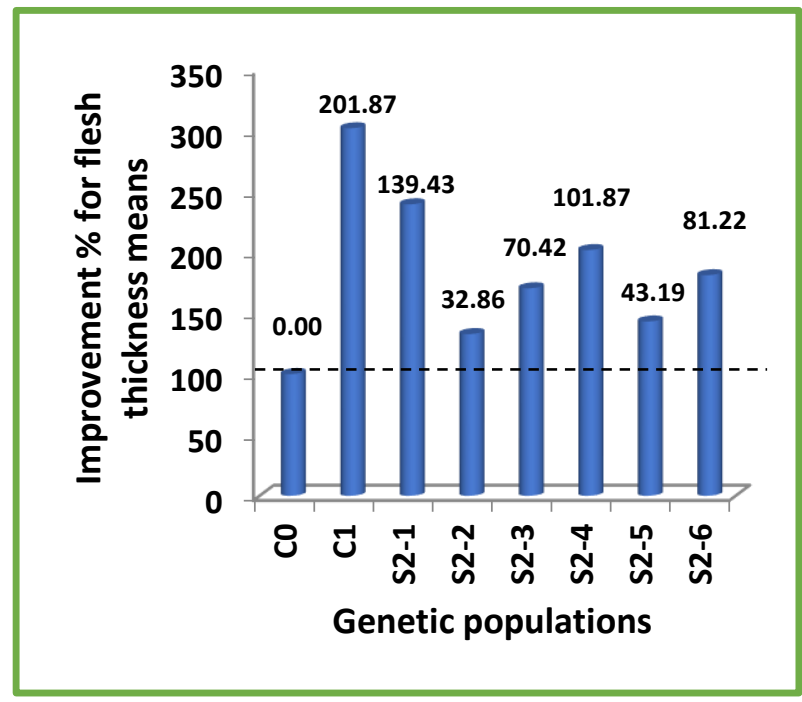

C

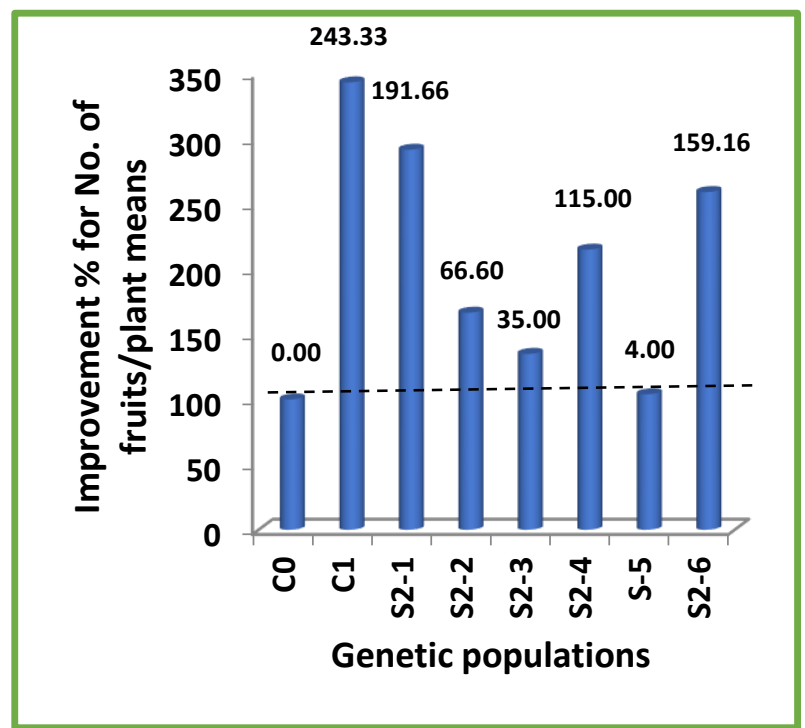

b
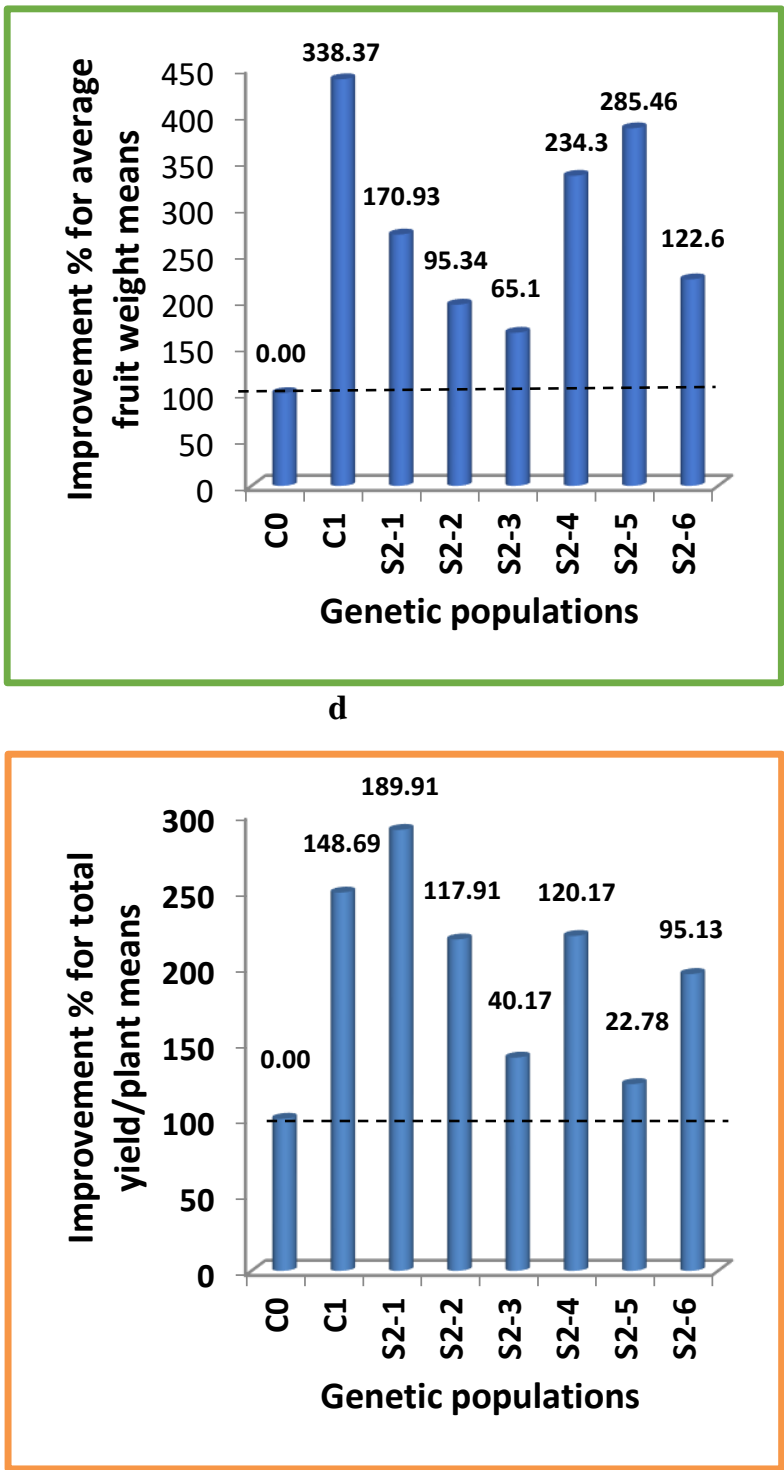

Fig. 2. The enhancement percentage for fruits and yield characters in the selected genetics populations as compared to the original population.

$\mathrm{C}_{0}=$ The original population of pumpkin cultivar " Balady".

$\mathrm{C}_{1}=$ The population derived from the first cycle of simple recurrent selection.

$\mathrm{S}_{2}-1$ : $\quad \mathrm{S}_{2}-6 \quad$ The $\quad$ six $\quad$ selected progenies derived from selfing with selection for two generations. 
all selected populations showed significant superiority in total sugars over their original population. The total sugars of $C_{1}, S_{2}-6$ and $S_{2}-4$ populations significantly possessed the highest values of $7.31 \%, 6.84 \%$, and $6.64 \%$, respectively. Variability magnitude for chemical constituents of fruits characters indicated that the variability of these characters was reduced, but with different relative magnitudes, in all selected populations; in comparison with the original population (Table 4). The estimated C.V. \% value for dry matter percentage was reduced from $36.47 \%$ in $\mathrm{C}_{0}$ to $22.68 \%$ in $\mathrm{C}_{1}$ population. In the case of selfing with selection, the reduction in variability was more severe in progeny $\mathrm{S}_{2}-2(18.53 \%)$ than the other five selfed progenies populations. While, for the total soluble solids, C.V.\% values were $26.86 \%$ in $\mathrm{C}_{0}$ population and $20.42 \%$ in $\mathrm{C}_{1}$. In the case of selfing with selection for two generations, the variability was noticed to reflect more reducing effect, since the C.V. \% values of the six selfed progenies were estimated with lower values from $19.25 \%$ to $11.14 \%$ than that of the original population. For carotene content character, the results illustrated that the reduction in variability after one cycle of recurrent selection relatively seemed to be reasonable, from $37.18 \%$ in $\mathrm{C}_{0}$ to $20.08 \%$ in $\mathrm{C}_{1}$; whereas, in the case of selfing with selection populations, such reduction was noticed to be moderate for three progenies $\left(S_{2}-1, S_{2}-3\right.$ and $\left.\mathrm{S}_{2}-5\right)$ and was severe for the other three progenies $\left(S_{2}-6, S_{2}-4, S_{2}-2\right)$. Where, the coefficient of variations ranged from $11.94 \%$ to $28.66 \%$. Moreover, the variability in total sugar character, in general, was reduced in all derived populations

with different magnitudes from that of the original population. The coefficient of variation values reflected clear reduction in variability magnitude in $\mathrm{C}_{1}$ population as well as the progenies of selfing with selection. Where, the C.V. \% value was estimated by $64.85 \%$ in $\mathrm{C}_{0}$ and by a severe lower value of $12.91 \%$ in $\mathrm{C}_{1}$. Moreover, selfing with selection reduced the variability in all selfed progenies, which gave C.V. \% values ranged from $12.41 \%$ to $17.83 \%$.

The percentages of improvement in mean values of chemical constituents of fruits characters for all selected populations over that of the original population are presented in Fig. 3. The highest increase in dry matter percentage was reflected by $C_{1}$ population with about $199.44 \%$, followed by $\mathrm{S}_{2}-3$ and $\mathrm{S}_{2}-1$ with about $157.61 \%$ and $114.40 \%$, respectively (Fig. 3 a). The percentage of improvement in total soluble solids for the selected populations (Fig. $3 \mathrm{~b}$ ) reflected that the second selfed progenies $S_{2}-1, S_{2}-4$ and $S_{2}-3$ recorded high efficiency to increase total soluble solids with about $127.51 \%, 116.46 \%$ and $94.59 \%$, respectively. In the case of the first recurrent selection cycle, the improvement was around $80.83 \%$ relative to the original population. For carotene content character, $\mathrm{S}_{2}-5, \mathrm{~S}_{2}-6$ and $\mathrm{C}_{1}$ reflected increment with about $72.60 \%, 38.64 \%$ and $30.01 \%$, respectively, over that of $\mathrm{C}_{0}$ population. The increase rate was relatively small in $\mathrm{S}_{2}-4$ and $\mathrm{S}_{2}-1$ with about $16.32 \%$ and $5.81 \%$. On the other hand, the two selfed progenies $\mathrm{S}_{2}-2$ and $\mathrm{S}_{2}-3$ reflected reduction percentage by $11.26 \%$ and $30.21 \%$, respectively, compared with $\mathrm{C}_{0}$ (Fig. 3 c). The results reflected high improvement for total sugars means in all derived genetic populations (Fig. $3 \mathrm{~d}$ ). Where, $\mathrm{C}_{1}, \mathrm{~S}_{2-}$, $\mathrm{S}_{2}-4, \quad \mathrm{~S}_{2}-2$, and $\mathrm{S}_{2}-1$ recorded highly efficient increase in total sugars character with about $87.43 \%, 75.38 \%, 70.25 \%, 64.61 \%$ and $54.61 \%$; respectively, over that of the original population. The other progenies $\mathrm{S}_{2}-3$ and $\mathrm{S}_{2}-5$ increased this character by only $42.56 \%$ and $20.00 \%$, respectively. 
A

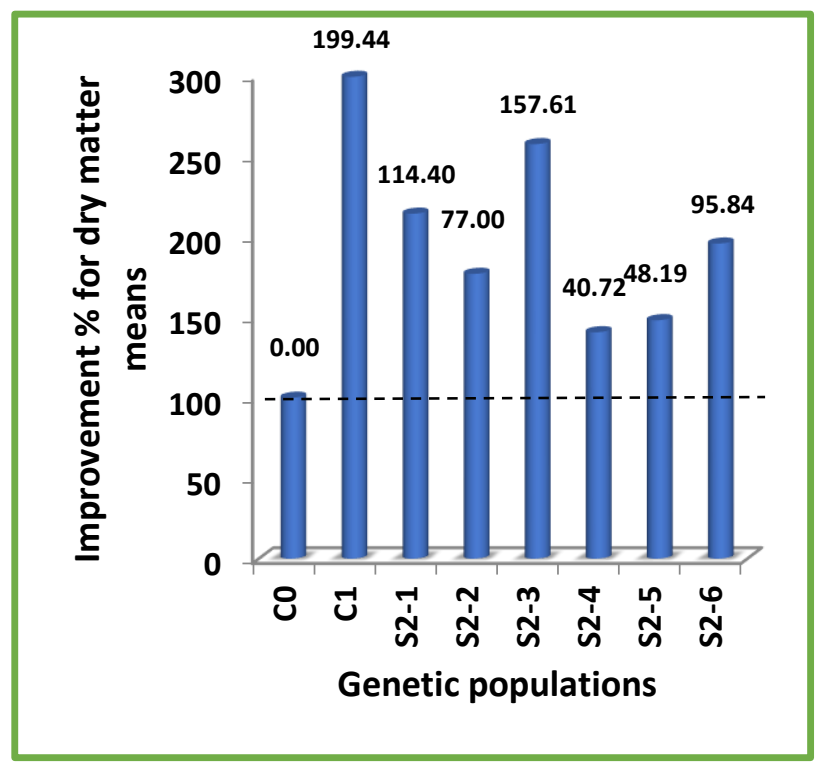

C

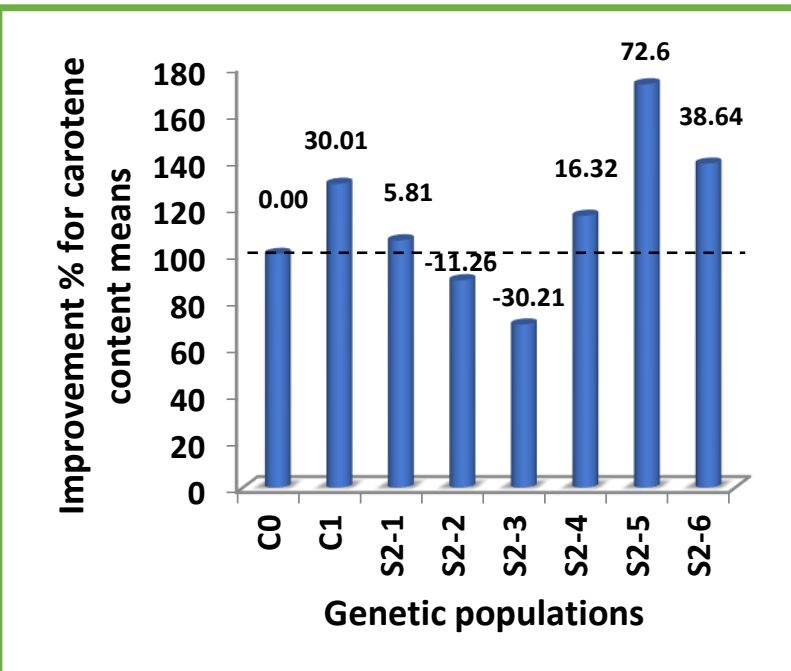

B

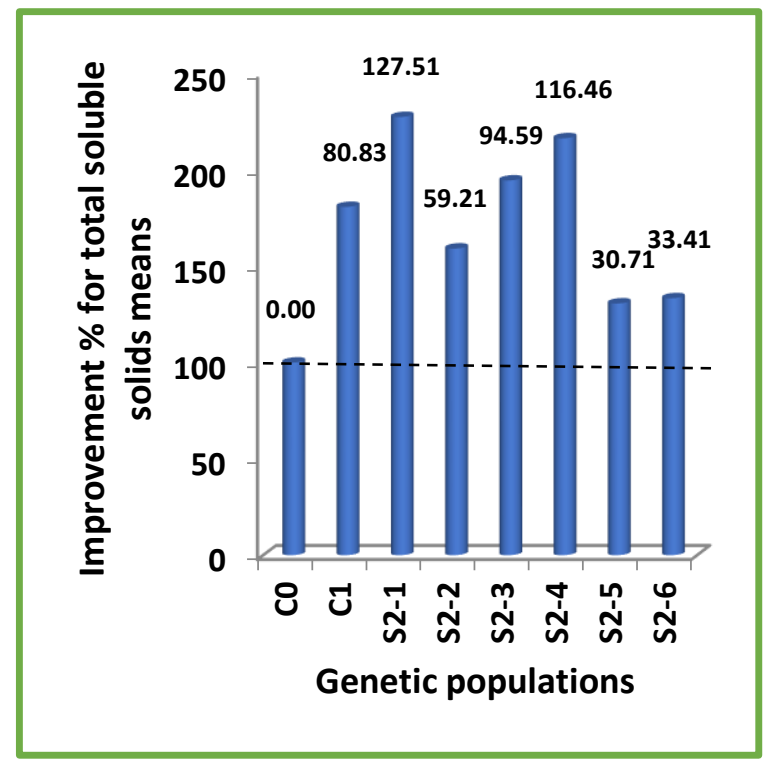

D

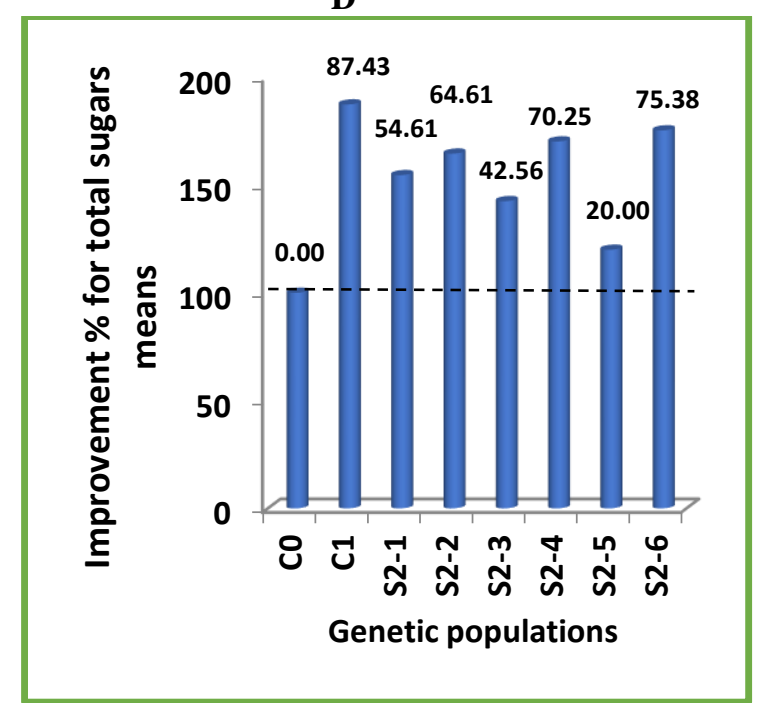

Fig. 3. The enhancement percentage for chemical constituents of fruits characters in the selected genetics populations as compared to the original population.

$\mathrm{C}_{0}=$ The original population of pumpkin cultivar " Balady".

$\mathrm{C}_{1}=$ The population derived from the first cycle of simple recurrent selection.

$S_{2}-1: S_{2}-6=$ The six selected progenies derived from selfing with selection for two generations. 
Total Variance Components and Heritability Percentages

The estimated values of total variance components and broad sense heritability percentages of the various studied characters are presented in Table (5). The comparison between total variance components showed that the estimates of genetic variance $\left(\sigma_{\mathrm{g}}^{2}\right)$ obviously reflected obviously higher values than that of

Table 5. Estimates of total variance components and heritability percentages for the studied characters on different genetic populations.

\begin{tabular}{|c|c|c|c|c|}
\hline Characters & $\sigma_{\mathrm{e}}^{2}$ & $\sigma^{2} g$ & $\sigma_{p}^{2}$ & $\mathbf{h}^{2}$ bs $\%$ \\
\hline Main stem length (m) Main & 0.23 & 3.89 & 4.13 & 94.18 \\
\hline No. of branches /plant & 0.29 & 1.48 & 1.77 & 83.61 \\
\hline $\begin{array}{l}\text { No. of days to first female } \\
\text { flower }\end{array}$ & 1.61 & 8.58 & 10.19 & 84.20 \\
\hline Sex ratio $(\%)$ & 0.50 & 7.63 & 8.13 & 93.74 \\
\hline Flesh thickness (cm) & 0.01 & 1.86 & 1.87 & 99.46 \\
\hline Average fruit weight $(\mathbf{k g})$ & 0.01 & 3.93 & 3.95 & 99.49 \\
\hline No. of fruits/plant & 0.11 & 1.21 & 1.32 & 91.66 \\
\hline Total yield/plant (kg) & 0.29 & 13.54 & 13.83 & 97.90 \\
\hline Dry matter $(\%)$ & 0.53 & 5.32 & 5.86 & 90.78 \\
\hline Total soluble solids (T.S.S) \% & 0.20 & 3.25 & 3.46 & 93.93 \\
\hline $\begin{array}{l}\text { Carotene } \\
(\mathrm{mg} / \mathbf{1 0 0 g m . f w})\end{array}$ & 0.04 & 2.88 & 2.92 & 98.63 \\
\hline Total sugars (\%) & 0.16 & 1.27 & 1.43 & 88.81 \\
\hline
\end{tabular}

$\sigma_{\mathrm{p}}^{2}=$ Phenotypic variance.

$\sigma_{\mathrm{g}}^{2}=$ Genotypic variance.

$\sigma^{2}{ }_{\mathrm{e}}=$ Environmental variance (error mean square).

$\mathrm{h}^{2}{ }_{\mathrm{bs}} \%=$ Heritability in broad sense.

\section{DISCUSSION}

Variability Estimates for the Original Population of Pumpkin:

The studied characters reflected high variability within the original population of pumpkin cultivar Balady. This variability supported the high possibilities of conducting successful and efficient selection to improve the different characters in the original pumpkin population and to introduce new developed population, which means that superior cultivars and inbred lines can be derived through practicing selection methods. The detected high variability was reflected also on the observed wide ranges. Such results appeared to be due to that 'Balady' cv. is comparatively an old one that is commercially grown for a long period without any kind of improvement or purification. Accordingly, it was expected that most of the studied characters could be improved through selection methods; but with varying degrees, depending on the amount of variation present in the population and heritability of the concerned characters. On the other hand, the efficiency of selection for number of days to first female flower was expected to be low, since these characters showed the lowest variability estimates in the environmental variance $\left(\sigma_{\mathrm{e}}^{2}\right)$ in all studied characters, suggesting that the differences in plant characteristics for the studied populations are due to genetic variance. High broad sense heritability values were recorded for all studied characters. It was found to be in the range of $83.61 \%$ for number of branches/plant up to $99.49 \%$ for average fruit weight.

ce $\left(\sigma^{2}\right)$ in all studied
that the differences in plant
studied populations are due
igh broad sense heritability
for all studied characters. It
the range of $83.61 \%$ for
plant up to $99.49 \%$ for (1) 
particular character. The differences between characters in the amount of variability maintained in the evaluated populations might be related to the degree of complication involved in their inheritance, the simply inherited characters are expected to show more reduction in variability than the quantitative ones in the early generations of selfing. The characters governed by small number of genes are expected to show more reduced variability than the characters governed by a large number of genes. However, it should be mentioned that the reduction in variability will continue for more and more generations in the case of the quantitative characters than that expected in case of qualitative or simply inherited characters.

Vegetative growth and flowering characters The variability estimate for main stem length and number of branches per plant in the original population was relatively higher; however, it was reduced in all selected populations. It was noticed that recurrent selection method tended to maintain relatively higher variability than selfing with selection method. Therefore, the first cycle of recurrent selection was apparently efficient in increasing the main stem length and number of branches/plant with about $122.6 \%$ and $157.50 \%$, respectively. Also, selfing with selection method for two generations enhanced main stem length within the range of $17.00 \%$ to $132.10 \%$, and number of branches per plant by $7.2 \%$ to $71.6 \%$ over that of the original population. The reduction in variability was detected in all selected populations relative to the original population, but with different degrees. These results agreed with the findings of Solieman (2009). The successful selection for this trait occurred and also related to the high heritability of this character which was $(94.18 \%)$ and was in harmony with that reported by Wang et al. (2012). The low value of number of days to first female flower and low value for sex ratio is desirable to improve these characters; it is expressed and associated with the early flowering for pumpkin crop. Such achieved improvements might be due to the noticed relatively high amounts of variability present in the original population as well as to the high heritability of these characters which was $84.20 \%$ for number of days to first female flower and $93.74 \%$ for sex ratio. These results are in harmony with those reported by Tsivelikas and Koutsika (2010), Akter et al. (2013), Ragheb 2016 and Srikanth et al. (2017).

Fruits, yield and its components characters

The great amount of variability for fruit flesh thickness that was present in the original population offered a good opportunity for realized improvements. The variability estimates were reduced in all selected populations compared to the original population. Moreover, such improvement related to high heritability which was $99.46 \%$. Results of heritability in the present study are in harmony with that reported by Pandey et al. (2002) and Akter et al. (2013) as well as Srikanth et al. (2017). They found that heritability for flesh thickness trait appeared to be high.

Generally, both of the first cycle of recurrent selection and selfing with selection for two generations methods resulted in obvious increments on both average fruit weight and number of fruits per plant. The percentages of increases reflected extremely increment of enhancement in the population of the first cycle of recurrent selection over that of the original population (increment reached $338.3 \%$ and $243.33 \%$ for the two characters, respectively). However, in the case of selfing with selection method the increase in average fruit weight was noticed to be within the range of $65.10 \%$ to $285.46 \%$, while in number of fruit/plant was noticed to be within the range of $4.00 \%$ to 191.66 $\%$ for all selected selfed progenies. These results are compatible with those of Tsivelikas and Koutsika (2010) and Aruah et al. (2012). The successful selection for these traits was related to the high heritability estimates of these characters. Total yield/plant increased after the first cycle of simple recurrent selection by $148.91 \%$. However, In case of selfing with selection for two generations, it was improved in most progenies by about $22.78 \%$ to $189.91 \%$, such result was in harmony with those of Solieman (2009), and Hazara et al. (2007). Moreover, this trait had a high heritability $(97.90 \%)$ which agreed with that reported by Akter et al. (2013).

Chemical constituents of fruits characters

The obtained results indicated that after the first cycle of recurrent selection the four chemical constituents of fruit characters significantly increased relative to the original population. Also, in the case of selfing with selection, the comparisons among the mean values clarified that almost all of the selected selfed progenies showed efficiency in increasing these characters higher than original population. Similar results were obtained by Hazara et al. (2007) and Solieman (2009). The great amount of variability that was present in the original population for these characters offered a good opportunity for realized improvements. Moreover, such improvement related to high heritability, where the heritability estimates for these characters appeared to be higher than $90.0 \%$ in all characters. Such result is compatible with Wang et al. (2012). In contrast, Akter et al. (2013) found that heritability value of total soluble solid and total sugar appeared to be low. These results, clearly, indicated that the recurrent selection as well as selfing with selection breeding methods was effective in 
raising the frequencies of the genotypes with increasing the general performances of these characters.

\section{CONCLUSION}

The results of the general performance of different studied characters for the various genetic populations of pumpkin, evidently, indicated that the two breeding methods one cycle of simple recurrent selection and selfing with selection for two generations were found to be efficient for improving the general performance and reducing the high variability of most of the studied characters relative to those of the original population. The first cycle of recurrent selection found to be apparently efficient in increasing and enhancement the general performances more than selfing with selection for two generations for most studied characters, except for number of days to first female flower and carotene content. Therefore, it may be concluded that recurrent selection seemed to be effective and efficient for development of improved commercial pumpkin cultivar 'Balady'; whereas, selfing with selection can be successfully used to develop inbred lines for the production of hybrid or synthetic cultivar, out of the common commercial one.

\section{REFERENCES}

Akter, S.; M. G. Rasul, A. K. Aminul Islam and M. M. Hossain. 2013. Genetic variability, correlation and path coefficient analysis of yield and quality traits in pumpkin (Cucurbita moschata Duch ex Poir). Bangladesh Journal of Plant Breeding Genetics. 26(1): 25-33.

Allard, R.W. 1960. Principles of Plant Breeding. Jon Wiley Sons. Ine. New York. London. Pp. 485. Al-Rawi, K. M. and A. M. Khalaf-Allah. 1980. Design and analysis of agricultural Experiments. Text Book. El-Mousil Univ. Press. Ninawa, Iraq. Pp. 487.

Al-Alsadon, H. H.; H. Hegazi and I. A. Almousa. 1998. Evaluation of local pumpkin genotypes in the central region of Saudi Arabia. American Society for Horticultural Research Service. Cucurbitaceae'98: 43-50.

Angel R. D.V., A. Campbell, T. J. K. Radovich, T. Silvasy, S. Moore, and M. B. Kantar. 2020. Quantitative Trait Loci (QTL) Analysis of Fruit and Agronomic Traits of Tropical Pumpkin (Cucurbita moschata) in an Organic Production System.

Horticulturae , 6(1),

14; https://doi.org/10.3390/horticulturae601001 4.

Äruah, C. B.; M. I. Uguru and B. C. Oyiga 2010. Nutritional evaluation of some Nigerian pumpkins (Cucurbita spp.). Fruit, Vegetable and Cereal Science and Biotechnology. 5 (2): 64-71.

Aruah, C. B.; M. I. Uguru and B. C. Oyiga. 2012. Genetic variability and inter- relationship among some Nigerian pumpkin assessions (Cucurbita sp). International Journal of plant Breeding. Global Science Books. 6(1):34-41.

Davies, B. H. 1976. Analysis of carotenoid pigment. In: T. W. Goodwin (ed.).Chemistry and Biochemistry of Plant. Plant pigments. Academic Press. London New York.

El-Soukkary. F.A.H. 2001. Evaluation of pumpkin seed products for bread fortification. Plant Foods for Human Nutrition 56: 365-384.

Grisales, S. O.; D. B. Garcia and F. A. Cabrera. 2009. Effect of inbreeding on the quality traits of squash fruit. Acta Agronomica. 58(3):140-144.

Hazara, P.; A. K. Mandal; A. K. Dutta and H. H. Ram. 2007. Breeding pumpkin (Cucurbita moschata Duch. ex Poir.) for yield and carotene. Acta Horticulture. 752:431- 435.

Jansi, V., V. Rajasree, R. Kumar, S. Praneetha and S. Rajeswari. 2018. Heterosis and inbreeding depression studies in pumpkin (Cucurbita moschata Duch. ex Poir.). Electronic Journal of Plant Breeding, 9 (3 ): 1031 - 1037. DOI: 10.5958/0975-928X.2018.00128.X

Malik, C. P. and M. B. Singh. 1980. Plant Enzymology and Histo-Enzmology. A Text Manual. Kalyani Publishers New Delhi.

Milorad M., G. Rocchetti, S. Krstić, A. Mišan, M. Brdar-Jokanović, F. Marcheggiani, $\underline{\text { E. }}$ $\underline{\text { Martinelli, L. Lucini }}$ and E. Damiani. 2021. Comparative In Vitro Antioxidant Capacity and Terpenoid Profiling of Pumpkin Fruit Pulps from a Serbian Cucurbita maxima and Cucurbita moschata Breeding Collection Antioxidants, 10(10),

1580; https://doi.org/10.3390/antiox10101580.

Pandey, S.; J. Singh, A. K. Upadhyay and D. Ram. 2002. Genetic variability for antioxidant and yield component in pumpkin (Cucurbita moschata Duch. ex Poir). Indian Society of Vegetable Science. 29 (2):123-126.

Pandey, S.; S. Kumar; B. R. Choudahry; D. S. Yadav and M. Rai. 2008. Component analysis in pumpkin (Cucurbita moschata Duch ex. Poir). Vegetable Science. 35(1):35-37.

Ragheb, E. I. 2016. Recurrent selection and selfing with selection as a tool for improvement of sweet melon (Cucumis melo var. aegyptiacus). Egyptian Journal of Horticulture. 2(43):12-22.

Solieman, T. H. 2009. Simple recurrent selection and selfing with selection as two breeding methods for improving pumpkin [Cucurbita moschata, Duchesne ex (Poir)]. Plants. Journal of the Advances in Agriculture Researches (Faculty of Agriculture of Saba Basha).14 (2):409-428.

Srikanth, M.; S. G. Bharad; L. B. Thulasiram and N. R. Potdukhe. 2017. Studies on genetic variability, heritability and genetic advance in pumpkin (Cucurbita moschata Duch ex Poir.). 
International Journal of Current Microbiology \& Applied Sciences. 6 (6):1416-1422.

Tsivelikas, A.L. and M. S. Koutsika. 2010. Inbreeding effects on a winter squash landrace. Journal of Agricultural Science. 148(6):695-708.
Wang, L.; T. Liu; Z. Dai; W. Shi; M. Tan and X. Xu. 2012. Combining ability and heritability of 12 quantitative traits in Cucurbita moschata. Chinese journal of Cucurbits \& Vegetables. 1:1115. 


\section{الملخص العربى}

\section{كفاءة الانتخاب المتكرر البسيط والتلقيح الذاتي مع الانتخاب لتحسين نمو ومحصول وجودة القرع العسلي}

نجلاء على رمضان عمر - عبد العزيز محمد خلف الله ـمحمود عبادي وهب الله ـ انتصار إبراهيم راغب قسم الخضر ـ كلية الزر اعة - جامعة الاسكندرية

من المهم ان يؤخذ في الاعتبار العمل نحو تطبيق برامج التربية الفعالة لتتقية وتحسين القرع العسلي. أجريت

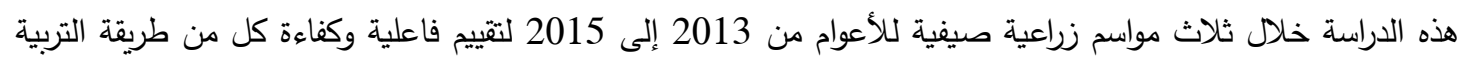

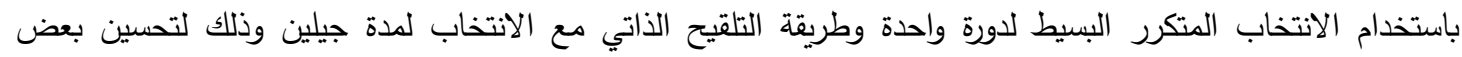

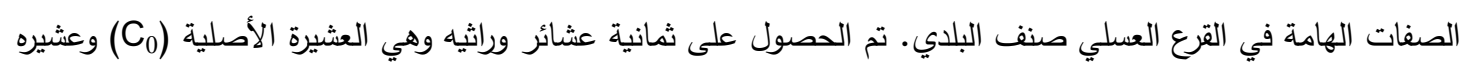

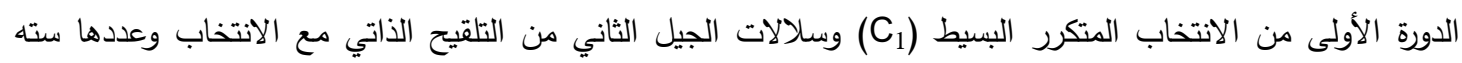

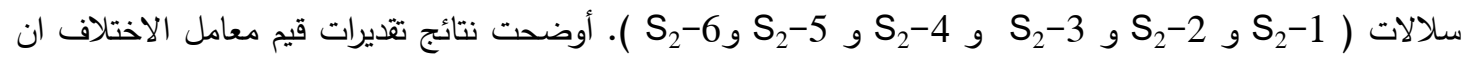

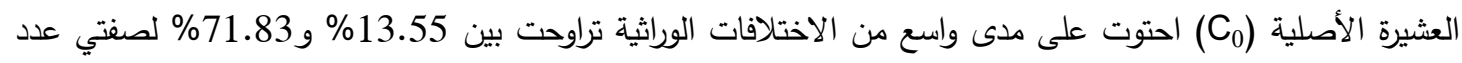

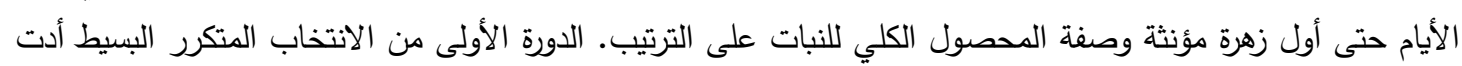

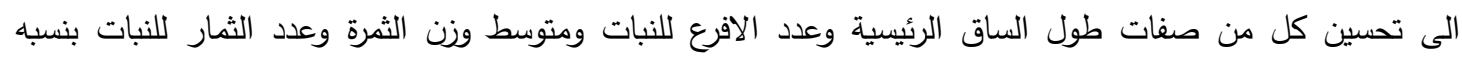

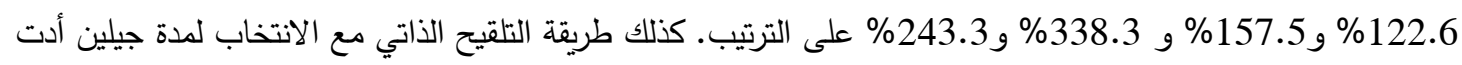

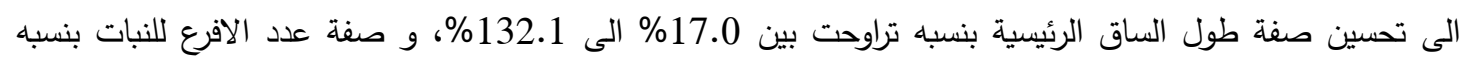

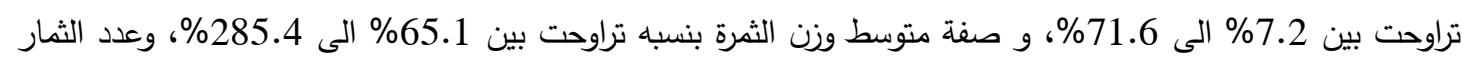

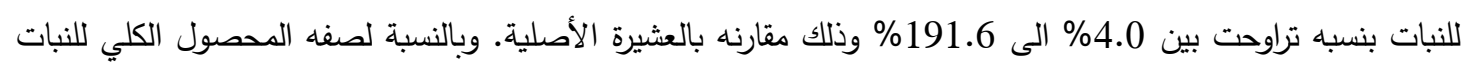

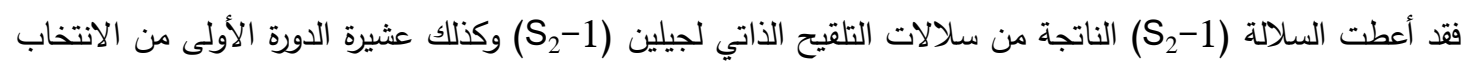

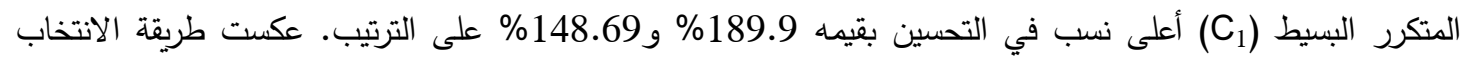

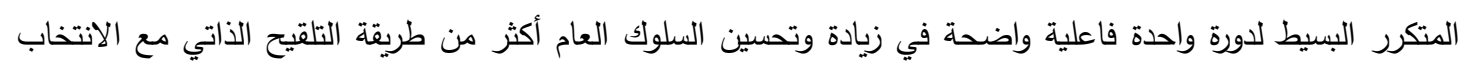

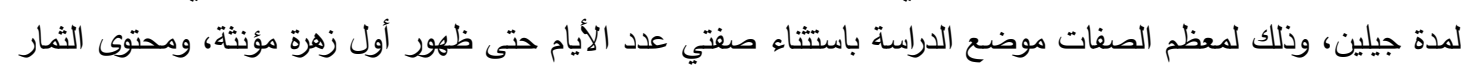

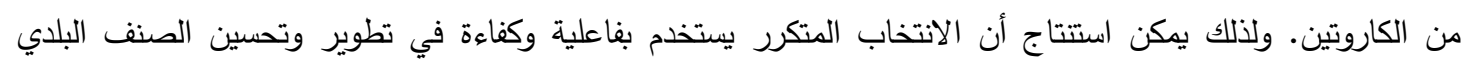

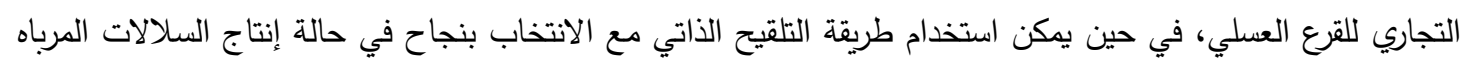

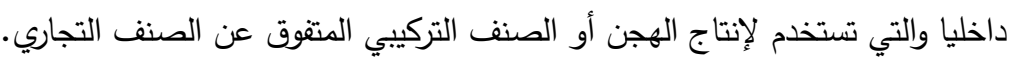

